NEWS

\title{
Italy puts seismology in the dock
}

\section{Scientists who assessed earthquake risk at L'Aquila could be indicted on manslaughter charges.}

\section{ROME}

The deadly earthquake that struck the central Italian city of L'Aquila on 6 April 2009, has had a bizarre aftershock: some of Italy's top seismologists could face charges of manslaughter for not alerting the population before the disaster. The indictment has outraged experts around the world, who note that earthquakes cannot be predicted and who say that the Italian government neglected to enforce building codes that could have reduced the toll.

The indictments, issued on 3 June by the L'Aquila public prosecutor's office, name six scientists as being investigated for manslaughter in relation to the earthquake. In Italy, this step usually precedes a request for a court trial, and is meant to allow the accused time to prepare their defence. The list comprises Enzo Boschi, president of the National Institute for Geophysics and Vulcanology (INGV) in Rome, the main institute in charge of seismic monitoring; Giulio Selvaggi, director of the National Earthquake Center based at INGV; Franco Barberi, a volcanologist at the University of 'Roma Tre'; Claudio Eva, a professor of earth physics at the University of Genoa; Mauro Dolce, head of the seismic risk office in the Italian government's Civil Protection Agency; and Gian Michele Calvi, director of the European Centre for Training and Research in Earthquake Engineering in Pavia. A government official, Bernardo De Bernardinis, deputy technical head of the Civil Protection Agency, is also under investigation.

\section{Assigning blame}

On 31 March 2009, all seven were in L'Aquila at a meeting of the Major Risks Committee, an expert group that advises the Civil Protection Agency on the risks of natural disasters. Frequent tremors had been recorded in the surrounding Abruzzo region, culminating in a magnitude- 4.0 earthquake on 30 March. The meeting was convened by the service to ask the scientists whether a major earthquake was on its way.

Immediately after that meeting, De Bernardinis and Barberi, acting president of the committee, held a press conference in L'Aquila, where De Bernardinis told reporters that "the scientific community tells us there is no danger, because there is an ongoing discharge of energy. The situation looks favorable". No other members of the committee were at the press conference. But on 6 April a magnitude- 6.3 earthquake struck L'Aquila, killing 308 people, leaving about 1,600 injured and more than 65,000 homeless. A group of local citizens later said that many of the earthquake's victims had been planning to leave their homes - but had
Survey in Pasadena, California. But Hough does disagree with some of the things said at the press conference. "The idea that minor earthquakes release energy and thus make things better is a common misperception. But seismologists know it's not true," she says. "I doubt any scientist could have said that."

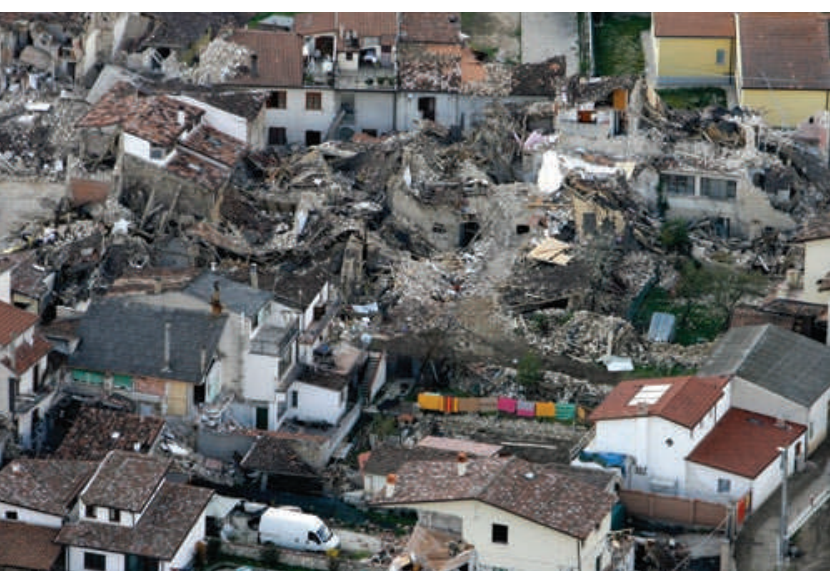
De Bernardinis, Boschi and Sel-
vaggi said that they were unable to comment on the case because of the ongoing investigation. Before the indictment, Boschi had criticized the Civil Protection Agency's handling of the 31 March meeting. "Such a meeting", he stated in a letter on $16 \mathrm{Sep}$ tember 2009 to Guido Bertolaso, the head of the Civil Protection Agency, "should have lasted hours if the Civil Protection Agency really wanted to consider all the data. Instead it only lasted one hour, and it was not followed by a joint statement but by a press conference about which we were not informed."

The Civil Protection Agency changed their minds after the committee's statements. In August 2009 they filed a formal request asking a prosecutor to investigate. L'Aquila's chief prosecutor, Alfredo Rossini, told the Italian press on 3 June that this had left him no choice but to proceed with an investigation and that his office had now gathered enough information to indict the individuals named.

The minutes of the 31 March meeting, though, reveal that at no point did any of the scientists say that there was "no danger" of a big quake. "A major earthquake in the area is unlikely but cannot be ruled out," Boschi said. Selvaggi is quoted as saying that "in recent times some recent earthquakes have been preceded by minor shocks days or weeks beforehand, but on the other hand many seismic swarms did not result in a major event". Eva added that "because L'Aquila is in a high-risk zone it is impossible to say with certainty that there will be no large earthquake". Summing up the meeting, Barberi said, "there is no reason to believe that a swarm of minor events is a sure predictor of a major shock". All the participants agreed that buildings in the area should be monitored urgently, to assess their capacity to sustain a major shock.

"These are the only sensible statements any scientist could make at that point," says Susan Hough, a geophysicist at the US Geological responded by asking Boschi why he waited six months before objecting to the nature of the meeting, and stated that Boschi "never explained what specific actions" the department should have taken to reduce the risks from a potential earthquake.

\section{Solidarity}

Staff at INGV have signed a letter of solidarity with Boschi and Selvaggi. Seismologists worldwide have also rallied to the defence of the scientists, with almost 4,000 researchers from 100 different countries signing a letter to Giorgio Napolitano, Italy's president, urging decision-makers to concentrate on "earthquake preparedness and risk mitigation rather than on prosecuting scientists for failing to do something they cannot do yet - predict earthquakes".

Barry Parsons, at the department of earth sciences at the University of Oxford, who signed the letter, says that Italy's maps of seismic risk are of the highest possible standard, and clearly show that Abruzzo is a very high-risk area. "The proven and effective way of protecting populations is by enforcing strict building codes," he says. "Scientists are often asked the wrong question, which is 'when will the next earthquake hit?' The right question is 'how do we make sure it won't kill so many people when it hits?"' Nicola Nosengo 